\title{
Qualitative versus Quantitative Research in Marketing
}

Russel W. Belk

Kraft Foods Canada Chair in Marketing Schulich School of Business - York University - 4700 Keele Street

Toronto, Ontario - Canada M3J 1P3

e-mail: rbelk@schulich.yorku.ca

Recebido em 18 de março de 2013. Aprovado em 22 de março de 2013

Editor Responsável: Edson Roberto Scharf, Dr.

Autor convidado para edição especial

It is ironic that at a time when we have more quantitative data about consumers than ever before - so-called "big data," scanner data, loyalty program purchase histories, trails of Internet searches and social media activity, and much more that businesses nevertheless increasingly desire qualitative information. I am not talking about the ubiquitous focus groups which have long been a staple in exploratory marketing and advertising research. Such focus groups continue to be used, but they are one of the weakest techniques in qualitative research. The sort of qualitative consumer research I have in mind instead includes ethnography, netnography, videography, qualitative data mining, projective methods, various types of observation, and depth interviews. What these techniques potentially provide is more naturalistic 


\section{Qualitative versus Quantitative Research in Marketing}

insight into how individual consumers and groups of consumers behave in everyday life.

One example is the ethnographic research done by Proctor and Gamble's Gillette razors in India. Gillette has a dominant 80 percent share of the U.S. market with its Fusion ProGlide razor for which replacement cartridges sell for $\$ 4$ U.S.. It had 50 percent of the middle class Indian market as well, but virtually no sales of its expensive razors among poor urban and rural Indian men. It first tried to develop a less expensive razor which tested positively among Indian students at MIT (Nilsson 2012). But these students shaved like middle class American and Indian men - before a wall mirror with hot running water. So the company sent a team of ethnographers and designers to India in order to see how poorer Indian men without access to running water shaved. They did in-home observations, depth interviews, shop-alongs, and test shaves. They found that these men didn't shave every day and when they did they used a small mirror and a cup of water, often squatting down either outside or inside with poor lighting. They used a 100-year old technology of double-edged razor blades in a razor that opened to receive new blades. The outcome was many nicks and cuts.

As a result of this work, the design team developed the Gillette Guard-a plastic razor made in India with a large comb to prevent cuts and a design that allows easy cleaning without running water. The razor costs only 3 percent of what it costs to make the ProGlide razor and sells for 15 rupees (\$.30 US) with replacement cartridges costing one-third of this. Tests in India had shown many fewer nicks with the new razor and a great deal of satisfaction with the shave produced by the Guard. Based on the ethnography Gillette also knew they had to get distribution in the many small shops of India and that the use of
Bollywood actors in advertising the product would also be critical to its success. After introducing the razor in India in October 2010, it obtained an amazing 50 percent market share within 6 months. Furthermore, the product is now being introduced in China and other developing economies, with plans to eventually roll out the product in North American markets in order to safeguard against low cost disruptive innovations by competitors like Schick (Byron 2010; Govindarajan 2012).

These are the sorts of insights that executives living a life far removed from that of their customers are not apt to see. Nor are they likely to gain this level of understanding from quantitative data. Today many large firms including IBM, Intel, Motorola Microsoft, Toyota, and Nokia have anthropologists on their staff in order to provide ethnographic research of this sort for their corporate employers. Ethnographic and videographic research firms like Practica in New York and Chicago and Galileo Kaleidoscope in Sydney and Melbourne specialize in providing these types of qualitative research. As the principles of practica have observed, they have gone from providing occasional videos for their clients to having clients expect it to be a key part of every research project (Sunderland and Denny 2007). Sometimes they have consumers themselves shoot these videos on topics ranging from "using my pickup truck" to "college drinking" to "eating while driving."

While industry has led the way, many academic marketing departments now also specialize in qualitative consumer research, including the Universities of Wisconsin, California Irvine, Arizona, and Notre Dame in the U.S., York University in Canada, University College of London, the Universities of Bath, Lancaster, Strathclyde, Exeter, and Durham in the U.K., the 


\section{Russel Belk}

University of Southern Denmark, Lille University in France, Aalto University in Finland, University of Sydney in Australia, and a number of others. Consumer Culture Theory conferences each year showcase this research, as do the Association for Consumer Research Conferences, Transformative Consumer Research Conferences, the Anthropology of Markets and Consumption conference, and the Ethnographic Praxis in Industry Conferences. There are also a number of books devoted to qualitative consumer and market research (e.g., Belk 2006; Belk, Askegaard, and Scott 2012; Belk, Kozinets, and Askegaard 2013; Kozinets 2010; Gordon and Langmaid 1988; Mariampolski 2006) as well as the Association for Consumer Research Film Festivals and an online site called Films by Consumer Researchers (http://vimeo.com/groups/136972). The Qualitative Market Research journal specializes in such research while a number of other marketing and consumer research journals also publish an increasing amount of qualitative work.

Despite this growth, quantitative consumer and marketing research remains more prevalent than qualitative work in both industry and academia. While I believe that qualitative methods are still vastly underutilized in consumer research given their potential, it is important to recognize that qualitative and quantitative methods do not directly compete with one another for any given theoretical or applied problem. They can in fact be complimentary. As my colleagues and I (Belk, Fischer, and Kozinets 2013) emphasize, the two types of research differ from one another in four primary ways:

1. Qualitative Research provides richly detailed verbal and visual data rather than quantified data. While quantitative research's distillation of responses into numbers allows sometimes powerful statistical manipulations of data, qualitative research potentially creates a rich portrait of people and behaviors that are closer to the way consumers normally behave and speak.

2. Qualitative Research provides contextualized rather then decontextualized views of consumption and marketing. That is, quantitative research assumes that the way consumers behave is the same regardless of the situation, the researcher, and the time and place of data collection. Qualitative research rejects these assumptions and examines how consumers behave in specific situations that vary with the season, the weather, other people who are present, and so forth.

3. Qualitative Research ideally takes place in naturally occurring situations rather than in situations controlled by the researcher. Quantitative researchers, at least those using experimental methods, manipulate elements of the marketing mix in order to predict the impact these changes will have on consumer attitudes or behavior. The trade-off in doing so is the researcher's inability to examine the behavior in natural contexts with a myriad of other variables also in play.

4. The researcher is involved as a key instrument in gathering qualitative researcher rather than attempting to a detached approach where the researcher is effectively absent. While qualitative researchers rely on building trust, familiarity, and rapport with consumers in order to get good data, quantitative researchers rely on anonymity. There is accordingly more subjecttivity in qualitative research but also more human interaction and connection.

As a consequence of these differences, qualitative research tends to involve smaller numbers of consumers examined in finer detail. Quantitative data tend to be more representative but more superficial. Thus, for example in order to 


\section{Qualitative versus Quantitative Research in Marketing}

estimate attendance at an event, quantitative data are often superior. But this isn't necessarily the case. Quantitative studies have attempted to predict attendance at new motion picture films by using consumer preference measures and by modeling past attendance figures to the film's actors, director, genre, promotional budget, and other objective variables. But qualitative studies have examined how people actually decide what film to see in natural situations. They find that people seldom go to movies alone and that despite individual tastes, the couple or group often selects the film that is least objectionable to the group, even though it may be no one's first choice. As a result the quantitative models of individual preferences do a poor job of predicting actual attendance. Quantitative research is also better suited to trying to understand online comments on new films in blogs, on social media, and within forums and chat rooms. Although there are computer programs that attempt to quantify such data, the nuances, sarcasm, and humor often found in such exchanges are usually better analyzed qualitatively.

This is not to say that research cannot often be both qualitative and quantitative, since both bring something different to our understanding. Furthermore, all research is interpretive, regardless of whether words and images or numbers and statistics comprise the data that are being interpreted. Different sets of skills are needed for the two types of research and researchers often specialize in either qualitative or quantitative research. For example, the quantitative researcher may have skills in multivariate analysis, psychometrics, experimental design, structural equation modeling, and sampling, while the qualitative researcher may have skills in projective methods, visual elicitation, photography, videography, hermeneutics, and depth interviewing. The two sets of methods also differ in their underlying assumptions about the nature of reality, the nature of evidence, causality, and factors that shape behavior. Unfortunately these differences often evoke an "either/or" approach on the part of researchers and audiences for their research. In both academic and applied research it is usually far more beneficial to adopt a "both/and" perspective and to select the best tool for the problem at hand. Otherwise, with a tool kit comprised of only a single tool, the "law of the hammer" tends to apply. If you only have a hammer in your tool kit, everything starts to look like a nail and we keep pounding away, regardless of the nature of the problem at hand.

\section{References}

BELK, R., ed. Handbook of qualitative research methods in Marketing. Cheltenham, UK: Edward Elgar, 2006.

BELK, R.; ASKEGAARD, S.; SCOTT, L. ed. Research in consumer behavior, v. 14, Bingley, UK: Emerald, 2012.

BELK, R.; FISCHER, E.; KOZINETS, R. V. Qualitative consumer and Marketing research, London: Sage, 2013.

BYRON, E. "Gillette's Latest Innovation in Razors: The 11-Cent Blade," Wall Street Journal, October 1, http://online.wsj.com/article/SB1000142405 2748704789404575524273890970954.html., 2010.

GORDON, W.; LANGMAID, R. Qualitative market research: A practitioner and buyer's guide, Aldershot, UK: Gower, 1988.

GOVINDARAJAN, V. "P\&G Innovates on Razor-Thin Margins," Harvard Business Review Blog, April 16, 


\section{Russel Belk}

http://blogs.hbr.org/cs/2012/04/how pg inn ovates_on_razor_thin.html., 2012.

KOZINETS, R. V. Netnography: Doing ethnographic research online, London: Routeldge, 2010.

MARIAMPOLSKI, H. Ethnography for Marketers: A guide to consumer immersion, Thousand Oaks, CA: Sage, 2006.

NILSSON, J. L. "Procter \& Gamble Innovates on Thin Margins in India," Photography and Visual Ethnography, June 5,http://jacoblangvad.com/articles/2012/06/p rocter-gamble-innovates-in-india/, 2012. 